\title{
UPAYA ORANG TUA DALAM MEMBENTUK KARAKTER ANAK DI DUSUN SUMBERSUKO DESA PLOSOSARI KECAMATAN GRATI KABUPATEN PASURUAN
}

\author{
Ali Muhsin \\ alimuhsin@fai.unipdu.ac.id
}

\begin{abstract}
Abstrak
Dalam membentuk karakter anak dimulai sejak dini bahkan sejak dalam kandungan ibu. Terdapat banyak faktor yang dapat membentuk karakter anak. salah satunya adalah orang tua yang lebih sering menghabiskan waktu bersama anak. Tujuan penelitian mengetahui upaya orang tua dalam membentuk karakter anak, mengetahui strategi yang dilakukan orang tua dalam membentuk karakter anak, mengetahui hambatan dalam membentuk karakter anak di dusun Sumbersuko desa Plososari kecamatan Grati kabupaten Pasuruan. Jenis penelitian kualitatif deskriptif. Sedangkan metode pengumpulan data yang digunakan yaitu observasi, wawancara dan dokumentasi. Hasil penelitian ini dapat disimpulkan bahwa upaya yang dilakukan orang tua dalam membentuk karakter anak dengan mendidik anak sejak usia dini dengan menanamkan pendidikan agama, nilainilai dan norma-norma dimana anak tinggal, strategi yang dilakukan yaitu keteladanan, pembiasaan, nasihat, reward dan punishment. Hambatan yang dihadapi adalah faktor internal yaitu kesibukan orang tua dan sifat bosan yang ada pada anak, faktor eksternal yaitu pengaruh lingkungan bermain dan pengaruh teknologi komunikasi.
\end{abstract}

Kata Kunci: Upaya, Orang Tua, Karakter anak.

\begin{abstract}
Character building of the child is started early. Even since in mother's womb. There are many factor that can build the character of the child, one of them is the parents who spend more time with their child. The aim of this research is to knowing the parent's effort in building the character of the child and knowing their obstacles in Sumbersuko Plososari Grati Pasuruan. The kind of this research is qualitative descriptive. And the method to collect data used is observation, interview, and documentation. The result of this research can be concluded that the parent's effort in building character of the child is started early by teaching religious education and teaching values and norms where child lives. The strategies used is exemplary, habitution, advice, reward and punishment. The obstacles in building the character of the child from internal factor is the parent's bustle and children's boredom. While the external factor is environmental influences and technology communication influences.
\end{abstract}

Keyword: Effort, Parent's, Character. 


\section{Ali Muhsin}

\section{A. Pendahuluan}

Peran orang tua dalam mendidik anak. Orang tua adalah ayah dan ibu kandung, atau orang yang disebut tua atau dituakan atau orang yang disegani atau diharmati dalam suatu masyarakat. Dengan demikian orang tua adalah ayah dan ibu kandung atau masyarakat secara keseluruhan.

Orang tua dalam keluarga selalu mengupayakan anaknya menjadi yang terbaik, maka dari itu orang tua memposisikan dirinya sebagai motivator, fasil atator, mediator. Orang tua merupakan tempat bimbingan yang pertama dalam hal membentuk karakter seorang anak. Anak bukan saja membutuhkan pemenuhan material tetapi juga kasih sayang, perhatian, dorongan, dan keberadaan orang tua disisinya. Orang tua di sini lebih condong pada sebuah keluarga, dimana kelurga adalah sebuah kelompok primer yang paling penting di dalam masyarakat.

Menurut Zakiyah Daradjat: “Orang tua harus memperhatikan pendidikan anaknya, justru pendidikan yang diterima dari orang tua yang menjadi dasar pembinaan karakter anak. Dengan begitu orang tua jangan sampai membiarkan pertumbuhan si anak berjalan tanpa bimbingannya atau hanya diserahkan pada guru di sekolah saja. Partisipasi orang tua sangatlah penting dalam pendidikan anak, karena bukan hanya di sekolah anak harus mendapat pendidikan tapi juga di rumah bersama keluarga yaitu pendidikan dari ayah dan ibu. 


\section{Upaya Orang Tua Dalam Membentuk Karakter Anak Di Dusun Sumbersuko Desa Plososari Kecamatan Grati Kabupaten Pasuruan}

Sejak kelahirannya, manusia telah ditakdirkan miskin pengetahuan dan tak punya apa-apa kecuali ketidaktahuan atau ketidaksadaran maka dari itu, ia pun merengek, tulus, tanpa tuntutan, dan tak ternoda, tak ada tanda- tanda ia akan jadi orang oportunis saat ia dewasa. Jangan didik ia jadi orang yang oportunis, didiklah ia agar menjadi orang yang bermartabat. Untuk itu, tugas orang tua menjadikan anak yang bermartabat dan berkarakter yang baik.

Ibu adalah orang yang sangat berjasa bagi anak mulai dari mengandung, melahirkan dan menyusui semua itu merupakan kepedihan baginya. Tapi setelah anak berada disisinya semua kepedihan itu berubah menjadi kebahagiaan yang tidaka ada tandingannya. Bahkan setelah kepedihan itu terlupakan ibu masih banyak berkorban, dia rela tidak tidur untuk menjaga anaknya yang rewel. Dan begitu banyak lagi pengorbanan seorang ibu.

Oleh karena itu Allah SWT. menjadikan surga ditelapak kaki ibu dan menjadikan ha nya atas anak tiga kelipatan hak ayah. Dalam sebuah hadits di sebutkan sebagai berikut: ${ }^{1}$

Artinya: Dari Abu Hurairah ra., ia berkata: "Kali tertentu seorang lelaki datang kepada Rasulullah saw. Lalu bertanya: “Wahai Rasulullah, siapakah yang paling berhak aku pergauli dengan baik?" Rasulullah menjawab: “Ibumu!" Lalu siapa?" Rasulullah menjawab: "Ibumu!" Sekali lagi orang itu bertanya:

\footnotetext{
${ }^{1}$ Imam Nawawi, Terjemah Riyadhus Shalihin Jilid 1 (Jakarta: Pustaka Amani, 1999), 327.
} 


\section{Ali Muhsin}

“Kemudian siapa?” Rasulullah menjawab: “Bapakmu!” (HR. Bukhari dan Muslim).

Keluarga sebagai salah satu dari tri pusat pendidikan, bertugas membentuk kebiasaan-kebiasaan (habit formation) yang positif yaitu sebagai fondasi yang kuat dalam pendidikan informal. Dengan kebiasaan-kebiasaan tersebut anak akan mengikuti/menyesuaikan diri bersama keteladanan orang tuanya. Namun kesibukan kerja dan dinamika kehidupan masyarakat modern sering kali memaksa orang tua meninggalkan tugas pokok mereka sebagai pendidik anak mereka ketika di rumah. Hali ini terjadi karena kebersaman mereka dengan anak semakin sedikit.

Di dusun Sumbersuko desa Plososari kecamatan Grati kabupaten Pasuruan dalam proses pembentukan karakter anak sebaiknya harus lebih diperhatikan, sehubungan dengan belum sepenuhnya tugas orang tua terlaksana. Padahal keluarga sebagai salah satu dari tri pusat pendidikan, bertugas membentuk kebiasaan-kebiasaan (habit formation) yang positif yaitu sebagai fondasi yang kuat dalam pendidikan informal. Dengan pembiasaan- pembiasaan tersebut anak akan mengikuti/menyesuaikan diri bersama keteladanan orang tua.

Terdapat beberapa orang tua yang belum sepenuhnya bisa melaksanakan tugasnya, karena alasan ekonomi yang mengharuskan orang tua harus jauh dengan anak. Tapi juga ada orang tua yang walaupun bersama anak setiap hari 


\section{Upaya Orang Tua Dalam Membentuk Karakter Anak Di Dusun Sumbersuko Desa Plososari Kecamatan Grati Kabupaten Pasuruan}

tapi membiarkan anaknya berbuat semaunya sendiri, tanpa dihiraukan apa perbuatannya benar atau salah, pantas atau tidak pantas. Tapi juga masih banyak orang tua yang sudah melaksanakan tugasnya sebagai orang tua. Orang tua yang belum bisa melaksanakan tugas dan perannya atau bahkan yang tidak mau melaksakan perannya menyerahkan tugasnnya pada guru sekolah anaknya tersebut. Jadi masih orang tua menganggap peran guru lah yang sangat berpengaruh pada karakter anak.

Dari latar belakang tersebut peneliti akan melakukan penelitian dengan judul: Upaya Orang Tua Dalam Membentuk Karakter Anak Di Dusun Sumbersuko Desa Plososari Kecamatan Grati Kabupaten Pasuruan.

\section{B. Problem Akademik}

Problem akademik dalam penelitian ini yaitu: Bagaimana upaya orang tua dalam membentuk karakter anak di dusun Sumbersuko desa Plososari, Strategi yang dilakukan orang tua dalam membentuk karakter anak di dusun Sumbersuko desa Plososari, hambatan dalam upaya orang tua dalam membentuk karakter anak di dusun Sumbersuko desa Plososari.

\section{Penelitian Terdahulu}

Penelitian terdahulu merupakan kajian-kajian penelitian yang dilakukan oleh peneliti terdahulu yang terkait. Ada beberapa penelitian yang berkaitan dengan pembahasan skripsi ini. Skripsi Jatien Sri Nandang, Jurusan Program 


\section{Ali Muhsin}

Pendidikan Guru Sekolah Dasar, Fakultas Keguruan dan Ilmu Pendidikan Universitas Muhammadiyah Surakarta 2015. Dengan judul "Peran Orang Tua Dalam Pembentukan Karakter Santun Pada Siswa SD Muhammadiyah Tegalgede Karanganyar." Hasil dari penelitian ini membahas tentang orang tua sangat berperan dalam membentuk karakter santun anak. ${ }^{2}$

Sedangkan penelitian yang diteliti sekarang yaitu peran orang tua dalam membentuk karakter anak secara umum. Skripsi Herlinawati, Fakultas Tarbiyah Universitas Islam Negeri Sunan Kalijaga Yogyakarta yang berjudul "Peranan Orang Tua Dalam Membentuk Kecerdasan Emosional Santri di Pengajian Anak-Anak Nur Farhan Papringan-Yogyakarta". Hasil penelitian skripsi di atas menjelaskan bahwa orang tua juga turut andil dalam membentuk kecerdasan emosional yang tergolong dalam 4 tahap. ${ }^{3}$ Sedangkan penelitian yang diteliti sekarang yaitu peran orang tua dalam membentuk karakter anak secara umum. Jurnal dari Suerlin Diah Utami, Jurusan Kurikulum dan Teknologi Pendidikan, Fakultas Ilmu Pendidikan Universitas Neger Semarang 2013. Dengan judul Peranan Orang Tua Dalam Mendidik Anak. Dalam penelitian ini peneliti membahas tentang pendidikan dari orang tuanya yang merupakan tanggung jawab orang tua untuk mendidik anak mereka karena orang tua disini adalah pendidik yang pertama dan

\footnotetext{
2 Jatien Sri Nandang, Peran Orang Tua Dalam Pembentukan Karakter Santun Pada Siswa SD Muhammadiyah Tegalgede Karanganyar (Skripsi , UNMU Surakarta, 2015), 64.

${ }^{3}$ Herlinawati, Peranan Orang Tua Dalam Membentuk Kecerdasan Emosional Santri di Pengajian Anak-Anak Nur Farhan Papringan-Yogyakarta (Skripsi, UIN Sunan Kalijaga, 2008), 108.
} 


\section{Upaya Orang Tua Dalam Membentuk Karakter Anak Di Dusun Sumbersuko Desa Plososari Kecamatan Grati Kabupaten Pasuruan}

utama bagi anak. ${ }^{4}$ Sedangkan penelitian yang diteliti sekarang yaitu peran orang tua dalam membentuk karakter anak secara umum.

\section{Metode Penelitian}

Penelitian ini dilakukan di dusun Sumbersuko desa Plososari kecamatan Grati kabupaten Pasuruan. Dengan menggunakan metode observasi, wawancara dan dokumentasi.

\section{E. Pembahasan}

Upaya merupakan proses dinamis suatu kedudukan. Peran dalam KBBI adalah perangkat tingkah yang diharapkan dimiliki oleh orang yang berkedudukan di masyarakat. ${ }^{5}$ Apabila seseorang melaksanakan hak dan kewajibannya sesuai dengan kedudukannya berarti dia menjalankan suatu peranan. Kedudukan dan peranan keduanya tidak dapat dipisahkan karena saling bergantungan satu sama lain. Arti peran dalam kamus besar bahasa indonesia adalah bagian yang dimainkan seorang pemain atau tindakan yang dilakukan oleh seseorang dalam suatu peristiwa.

Peran orang tua dalam keluarga itu adalah sebagai motivator, fasilatator, mediator. Orang tua merupakan tempat bimbingan yang pertama dalam hal membentuk karakter seorang anak. Anak bukan saja membutuhkan

\footnotetext{
${ }^{4}$ Suerlin Diah Utami, 'Peranan Orang Tua Dalam Mendidik Anak', Jurnal Skripsi, Vol. 02, No. 02 (april 1999), 89.

${ }^{5}$ Departemen Pendidikan Nasional, Kamus Besar Bahasa Indonesia (Jakarta: Balai Pustaka, 2001$), 854$.
} 


\section{Ali Muhsin}

pemenuhan material tetapi juga kasih sayang, perhatian, dorongan, dan keberadaan orang tua di sisinya. Orang tua di sini lebih condong pada sebuah keluarga, dimana kelurga adalah sebuah kelompok primer yang paling penting di dalam masyarakat.

Menurut Zakiyah Daradjat: “ orang tua harus memperhatikan pendidikan anaknya, justru pendidikan yang diterima dari orang tua yang menjadi dasar pembinaan karakter anak. Dengan begitu orang tua jangan sampai membiarkan pertumbuhan si anak berjalan tanpa bimbingannya atau hanya diserahkan pada guru di sekolah saja. Partisipasi orang tua sangatlah penting dalam pendidikan anak, karena bukan hanya di sekolah anak harus mendapat pendidikan tapi juga di rumah bersama keluarga yaitu pendidikan dari ayah dan ibu.

Sejak kelahirannya, manusia telah ditakdirkan miskin pengetahuan dan tak punya apa-apa kecuali ketidaktahuan atau ketidaksadaran makanya, ia pun merengek, tetapi murni, tulus, tanpa tuntutan, dan tak ternoda, tak ada tandatanda ia akan jadi orang oportunis saat ia dewasa. Jangan didik ia jadi orang yang oportunis, didiklah ia agar menjadi orang yang bermartabat. Untuk itu, tugas oarang tua menjadikan anak yang bermartabat dan berkarakter yang baik.

Di dalam keluarga sikap orang tua sangat menentukan karakter anak. Pada dasarnya orang tua ingin memberikan dan menjadi yang terbaik buat anak. Tapi terkadang orang tua salah dalam bersikap. Sikap orang tua yang selalu menuruti 


\section{Upaya Orang Tua Dalam Membentuk Karakter Anak Di Dusun Sumbersuko Desa Plososari Kecamatan Grati Kabupaten Pasuruan}

anaknya itu tidak baik. Terlalu menyayangi anaknya juga tidak baik. sebaiknya orang tua itu bersikap sesuai kebutuhan yang diperlukan anak.

Sikap yang pertama yang dibutuhkan anak adalah sikap yang menunjukkan bahwa mereka orang tua sayang pada anaknya. Seperti yang telah kita ketahui di dalam hati kedua orang tua secara fitrah akan tumbuh perasaan cinta terhadap anaknya dan akan tumbuh perasaan-perasaan psikologis lainnya, berupa perasaan kebapakan keibuan untuk memelihara, mengasihi, melindungi dan memperhatikan anak. ${ }^{6}$

Jika perasaan-perasaan psikologis semacam itu tidak ada, niscaya manusia ini akan lenyap dari permukaan bumi, dan kedua orang tua tidak akan sabar memelihara anak-anak mereka, tidak akan mau mengasuh dan mendidik, tidak akan mau memperhatikan persoalan dan kepentingan- kepentingan anaknya. ${ }^{7}$ Karena itu, orang tua harus menunjukkan bahwa mereka sayang dan peduli pada anaknya. Dengan begitu, anak akan mengetahui bahwa kedua orang tua mereka sayang pada mereka maka mereka (anak), akan merasa aman, keberadaannya sangat penting, dan anak akan merasa terlindungi.

Karakter merupakan hal yang sangat penting dan mendasar. Karakter adalah perilaku hidup yang membedakan manusia dengan binatang. Manusia tanpa karakter adalah manusia yang sudah membinatang. Sedangkan pengertian karakter menurut beberapa ahli yaitu menurut Simon Philips karakter adalah

\footnotetext{
${ }^{6}$ Abdullah Nashih Ulwan, Pendidikan Anak Dalam Islam 1, (Jakarta: Pustaka Amani), 207

${ }^{7}$ Ibid, 27.
} 


\section{Ali Muhsin}

kumpulan tata nilai yang menuju pada suatu sistem, yang melandasi pemikiran, sikap dan perilaku yang ditampilkan. ${ }^{8}$

Menurut Winnie istilah karakter mempunyai dua pengertian. Pertama, ia menunjukkan bagaimana seseorang bertingkah laku. Apa ia berperilaku tidak jujur, kejam, atau rakus maka itu disebut karakter buruk. Sebaliknya, apabila ia berperilaku jujur, suka menolong maka ia berkarakter baik atau mulia. ${ }^{9}$

Sedangkan menurut seorang filsuf yunani yang bernama Aristatoles mendefinisikan karakter yang baik sebagai kehidupan dengan melakukan tindakan-tindakan yang benar sehubungan dengan diri seseorang dan orang lain. Karakter, menurut pengamatan seorang filusuf kontemporer bernama Michael Novak, merupakan "campuran kompatibel dari seluruh kebaikan yang didefinisikan oleh tradisi religius. Cerita sastra, kaum bijaksana, dan kumpulan orang yang berakal sehat yang ada dalam sejarah." Sebagaimana yang ditunjukkan Novak, tidak ada seorang pun yang memiliki kebaikan itu, dan setiap orang memiliki beberapa kelemahan. Orang-orang dengan karakter yang sering dipuji bisa jadi sangat berbeda antara satu dengan lainnya.

Karakter itu terdiri dari nilai operatif, nilai dalam tindakan. Kita berproses dalam karakter kita, seiring suatu nilai menjadi suatu kebaikan, suatu disposisi batin yang dapat diandalkan untuk menanggapi situasi dengan cara yang menurut moral itu baik.

\footnotetext{
${ }^{8}$ Fatchul Mu'in, Pendidikan Karakter Konstruksi Teoritik \& Praktik, (Jogjakarta: Ar- Ruzz Media), 2011.

${ }^{9}$ Ibid, 160.
} 


\section{Upaya Orang Tua Dalam Membentuk Karakter Anak Di Dusun Sumbersuko Desa Plososari Kecamatan Grati Kabupaten Pasuruan}

Karakter yang demikian memiliki tiga bagian yang saling berhubungan: pengetahuan moral, perasaan moral, dan perilaku moral. Karakter yang baik terdiri dari mengetahui hal yang baik, menginginkan hal yang baik, dan melakukan hal yang baik-kebiasaan dalam cara berpikir, kebiasaan dalam hati, dan kebiasaan dalam tindakan. Ketiganya ini membentuk kedewasaan moral. Ketika kita berpikir tentang jenis karakter yang kita inginkan dan orang tua inginkan untuk anaknya, sudah jelas apa yang diinginkan itu untuk mampu menilai apa yang benar, sangat peduli tentang apa yang benar, dan kemudian melakukan apa yang diyakini mereka benar.

Dalam membentuk karakter seorang anak, orang tua banyak menemui dukungan maupun hambatan. Faktor penghambat bagi orang tua dalam membentuk karakter anak yaitu:Kurangnya waktu orang tua untuk memberikan perhatian dan kasih sayang pada anaknya, pigur orang tua yang tidak mampu memberikan keteladanan pada anak, sosial ekonomi orang tua yang kurang yang tidak bisa memenuhi seluruh kebutuhan anak, kasih sayang yang berlebihan yang diberikan oramg tua kepada anak, orang tua yang tidak bisa memberikan rasa aman kepada anak, tuntutan orang tua yang terlalu tinggi, Orang tua yang tidak bisa memberikan kepercayaan pada anak, Orang tua yang tidak bisa menumbuhkan inisiatif dan kreativitas kepada anak. ${ }^{10}$

\footnotetext{
${ }^{10}$ Fuad Ihsan, Dasar-Dasar Kependidikan: Komponen MKMD (Jakarta: PT: Rineka Cipta, 2010),
} 


\section{Ali Muhsin}

\section{F. Hasil Penyajian dan Analisis Data}

Sejarah Desa plososari sebenarnya tidak ada dalam sumber yang pasti. Namun menurut cAerita dari beberapa sumber yang dapat dipertanggungjawabkan kebenarannya, desa Plososari terbentuk pada tahun 1807 kedatangan seorang pengembara yang dari madura menuju ke jawa tepatnya sekarang di desa Plososari .

Semakin hari Plososari semakin ramai dan pada tahun 1919 Desa plososari sampai menjadi wilayah kadewanan plososari yang sekarang dikenal dengan sebutan Desa Plososari. Dengan memakai bahasa madura untuk bahasa keseharian. Adapun silsilah Kepemimpinan desa Plososari sebagai berikut:11 Wak inggi/ kepala desa: Mutiarum Memimpin tahun 1900-1945, Wak inggi/ kepala desa: Suriya Memimpin tahun 1945-1947, Wak inggi/ kepala desa : H. Abdulloh Memimpin tahun 1948-1960, Wak inggi/kepala desa : Suriya Memimpin tahun 1960-1963, Wak inggi/ kepala desa : H. Mahmud Memimpin tahun 1964-1980, PJ DES : Abdan Memimpin tahun 1981-1982, Wak inggi/ kepala desa: Abdan Memimpin tahun 1983-1995, Wak inggi/ kepala desa : Sunamar Memimpin tahun 1996-2012Wak inggi/ kepala desa : Suarli Memimpin tahun 2013 - sampai sekarang.

Desa Plososari ini dihuni penduduk sebanyak sebanyak 9080 jiwa, desa Plososari terdiri dari 5 dusun yaitu : dusun Sumbersuko, dusun Krajan, dusun Rembang, dusun Rembang Lor, dusun Tanah Celeng.

\footnotetext{
${ }^{11}$ Kholwani, Wawancara, 25 Desember 2017.
} 
Mengenai iklim desa Plososari pada umumnya adalah beriklim tropis yang terbagi menjadi 2 musim, yakni musim kemarau dan musim penghujan setiap tahunnya. Daerah batas-batas desa Plososari yaitu : Sebelah Utara: Sumber Dawe, SariSebelah Selatan: Perhutani, Sebelah Timur :Sanganom, Sebelah Barat: Kalipang.

\section{STRUKTUR PEMERINTAHAN DESA PLOSOSARI KECAMATAN GRATI KABUPATEN PASURUAN}

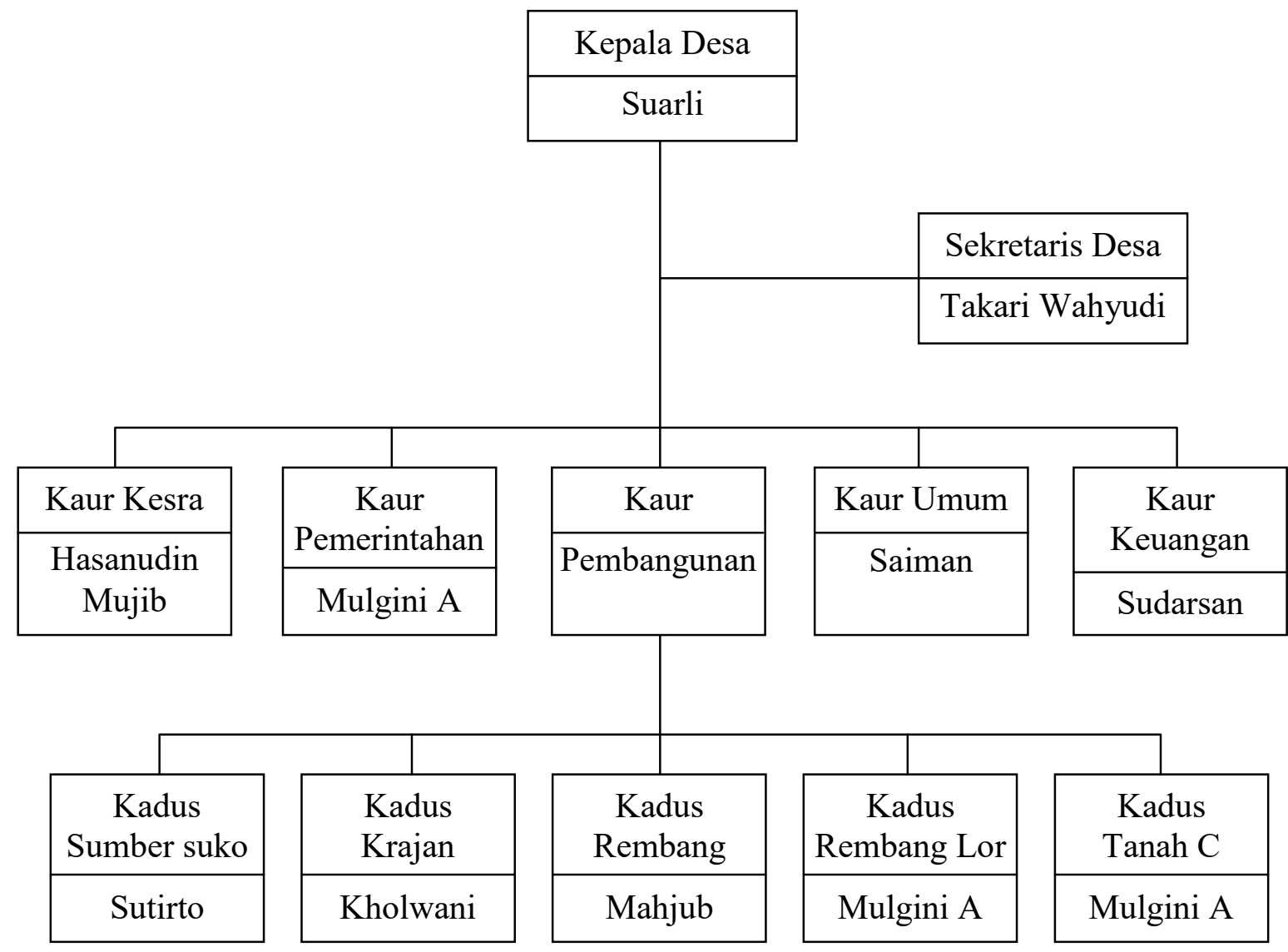

Gambar 1. Struktur Pemerintahan Desa Plososari Kecamatan Grati Kabupaten Pasuruan (Sumber Data: Kantor Desa Plososari Tahun 2016-2017) 


\section{Ali Muhsin}

Keadaan penduduk desa Plososari kecamatan Grati kabupaten Pasuruan, dapat dilihat pada table sebagai berikut:

Tabel 1. Jumlah Penduduk Desa Plososari Menurut Umur Tahun 2016-2017

\begin{tabular}{|c|c|c|}
\hline No. & Umur (Tahun) & Jumlah (Jiwa) \\
\hline 1. & $>65$ & 237 \\
\hline 2. & $60-65$ & 251 \\
\hline 3. & $55-60$ & 242 \\
\hline 4. & $50-55$ & 248 \\
\hline 5. & $45-50$ & 264 \\
\hline 6. & $40-45$ & 268 \\
\hline 7. & $35-40$ & 251 \\
\hline 8. & $30-35$ & 207 \\
\hline 9. & $25-30$ & 249 \\
\hline 10. & $20-25$ & 296 \\
\hline 11. & $15-20$ & 273 \\
\hline 12. & $10-15$ & 284 \\
\hline 13. & $5-10$ & 307 \\
\hline 14. & $<5$ & 283 \\
\hline \multicolumn{2}{|r|}{ Jumlah } & 9080 \\
\hline
\end{tabular}

(Sumber Data: Kantor Desa Plososari Tahun 2016-2017)

Pendidikan pada hakekatnya adalah usaha sadar untuk mengembangkan kepribadian dan kemampuan di dalam ataupun di luar sekolah dan berlangsung seumur hidup. Pendidikan dapat dinikmati atau dimiliki oleh setiap orang, sesuai dengan kemampuan masing-masing perorangan itu sendiri bahkan itu adalah menjadi tanggung jawab keluarga, masyarakat ataupun pemerintah. 
Upaya Orang Tua Dalam Membentuk Karakter Anak Di Dusun Sumbersuko Desa Plososari Kecamatan Grati Kabupaten Pasuruan

Tabel 2. Keadaan Penduduk Desa Plososari Tahun 2016-2017

\begin{tabular}{|c|l|c|}
\hline No & \multicolumn{1}{|c|}{ Kelompok Pendidikan } & Jumlah \\
\hline 1 & Belum Sekolah & 44 \\
2 & Tidak Tamat SD / Sederajat & 104 \\
3 & Tamat SD / Sederajat & 1596 \\
4 & Tamat SLTP / Sederajat & 420 \\
5 & Tamat SLTA / Sederajat & 346 \\
6 & Tamat D1, D2, D3 & 24 \\
7 & Sarjana / S1 & 9 \\
8 & Buta Aksara & 20 \\
\hline
\end{tabular}

(sumber data: Kantor Desa Plososari Tahun 2016-2017)

Tabel 3. Keadaan Sarana Pendidikan Desa Plososari tahun 2016-2017

\begin{tabular}{|c|l|c|c|c|c|c|}
\hline No. & \multicolumn{1}{|c|}{ Dusun } & SD & SLTP & SMU & PT & Jumlah \\
\hline 1 & Sumbersuko Barat & - & - & - & - & - \\
2 & Sumbersuko Selatan & - & - & - & - & - \\
3 & Krajan & 2 & 1 & - & - & 3 \\
4 & Rembang & - & - & - & - & - \\
5 & Tanah Celeng & 1 & - & - & - & 1 \\
\hline \multicolumn{2}{|c|}{ Jumlah } & 3 & 1 & - & - & 4 \\
\hline
\end{tabular}

(Sumber Data: Kantor Desa Plososari Tahun 2016-2017)

Keadaan sarana ibadah di desa Plososari kecamatan Grati Kabupaten

Pasuruan dapat dilihat pada tabel berikut ini :

Tabel 4. Keadaan Sarana Ibadah di Desa Plososari Tahun 2016-2017

\begin{tabular}{|c|l|c|}
\hline No & \multicolumn{1}{|c|}{ Sarana Ibadah } & Jumlah \\
\hline 1 & Masjid & 6 \\
2 & Musholla & 20 \\
\hline \multicolumn{2}{|c|}{ Jumlah } & 26 buah \\
\hline
\end{tabular}

(sumber data: Kantor Desa Plososari Tahun 2016-2017) 


\section{Ali Muhsin}

Keadaan penduduk desa Plososari kecamatan Grati kabupaten Pasuruan tahun 2016-2017, dapat dilihat pada table berikut ini:

Tabel 5. Mata Pencaharian Penduduk Desa Plososari

\begin{tabular}{|c|l|c|c|}
\hline No & \multicolumn{1}{|c|}{ Jenis Pekerjaan } & Jumlah & $\begin{array}{c}\text { Rata-rata } \\
\text { penghasilan/bln }\end{array}$ \\
\hline 1 & Petani & 4614 & Tidak pasti \\
\hline 2 & Buruh tani & 1528 & Tidak pasti \\
\hline 3 & Pegawai Negeri Sipil & 5 & 3 jt \\
\hline 4 & $\begin{array}{l}\text { Pengrajin industri rumah } \\
\text { tangga }\end{array}$ & 33 & 1,5 jt \\
\hline 5 & Pedagang keliling & 230 & 1 jt \\
\hline 6 & Peternak & 2500 & Tidak pasti \\
\hline 7 & Perawat swasta & 1 & Tidak pasti \\
\hline 8 & Pembantu rumah tangga & 216 & Tidak pasti \\
\hline 9 & $\begin{array}{l}\text { Pengusaha kecil } \\
\text { dan menengah }\end{array}$ & 314 & $4 j t$ \\
\hline 10 & Dukun Kampung Terlatih & 5 & Tidak pasti \\
\hline 11 & Jasa pengobatan alternatif & 2 & Tidak pasti \\
\hline 12 & $\begin{array}{l}\text { Karyawan perusahaan } \\
\text { swasta }\end{array}$ & 25 & $3,25 j t$ \\
\hline 13 & Sopir & 9 & 3,25jt \\
\hline 14 & Tukang Ojek & 5 & Tidak pasti \\
\hline 15 & Tukang Cukur & 250 & Tidak pasti \\
\hline 16 & Tukang Batu/ Kayu & 2,4jt \\
\hline
\end{tabular}

(Sumber Data: Kantor Desa Plososari Tahun 2016-2017)

Peneliti melakukan penelitian di desa Plososari tepatnya di dusun

Sumbersuko Barat yang dikepalai oleh Sutirto. Jumlah penduduknya sekitar 520 yang terdiri dari 90 KK. Penghasilan penduduk dari tani, mebel, kuli dan lainlainnya. Dan penghasilan dari pekerjaan tersebut bisa dibilang bahwa penduduk setempat pendapatannya menengah kebawah.

Upaya merupakan usaha untuk mencapai apa yang diinginkan. Orang tua di dusun Sumbersuko desa Plososari kecamatan Grati kabupaten Pasuruan 


\section{Upaya Orang Tua Dalam Membentuk Karakter Anak Di Dusun Sumbersuko Desa Plososari Kecamatan Grati Kabupaten Pasuruan}

dalam memberikan pendidikan karakter anak adalah dengan mendidik anak mulai dari usia dini dan diajari dengan suatu pembiasaan, karena dengan pembiasaan tersebut maka akan terbentuk karakter yang baik dan menjadi suatu kebiasaan dari kecil hingga seterusnya.

Seperti wawancara yang dilakukan pada tanggal 21 April 2017 dengan bapak Jumari (petani) yang mengatakan upaya dalam mendidik anak itu dimulai dari usia dini dengan menanamkan pendidikan agama. Memasukkan anak ke tempat pengajian (TPQ) dan menyekolahkannya. ${ }^{12}$

Dari hasil wawancara dengan bapak Jumari menunjukkan bahwa dalam membentuk karakter anak harus dimulai sejak dini, karena pada usia dini anak akan mudah menangkap apa yang diberikan oleh orang tuanya. Dalam membentuk karakter pada anak orang tua dapat mengenalkan pendidikan agama terlebih dahulu dengan mengenalkan dan mendekatkan pada Tuhan Yang Maha Esa.

Sebagaimana yang kita lihat sepulang dari SD anak-anak langsung pulang ke rumah. Pada jam 14.00 berangkat ke madrasah untuk menimba ilmu agama yang didalamnya terdapat pelajaran fikih, akhlaq dan tauhid.

Berdasarkan hasil observasi tanggal 22 April 2017, selain menyekolahkan anak ke madrasah orang tua juga mengajarkan anak-anak untuk mengaji. Terlihat pada pukul 16.00 anak berangkat bersama dan ada juga yang diantar langsung ke tempat ngaji (TPQ). Disana mereka belajar membaca Al-Qur'an,

\footnotetext{
${ }^{12}$ Jumari, Wawancara, Desa Plososari, 21 April 2017.
} 


\section{Ali Muhsin}

belajar do'a-do'a, dan membaca kitab. Hal ini bertujuan bertujuan untuk mengetahui tentang ilmu agama yang akan bermanfaat yaitu untuk membentuk anak memiliki karakter yang baik sesuai dengan perintah agama maka hidupnya akan terarah.

Orang tua di dusun Sumbersuko beranggapan bahwa jika pendidikan agamanya baik dan mengajinya lancar, maka anak itu mempunyai karakter yang baik. Sebaliknya jika pendidikan agamanya kurang dan mengajinya tidak lancar berarti anak tersebut mempunyai karakter yang kurang baik.

Hal serupa wawancara yang dilakukan pada tanggal 21 April 2017 dengan bapak Hartono (buruh) mengatakan ketika anak berumur 3-4 tahun mulai ditanamkan hal-hal yang baik dengan mengajari anak membaca do'a- do'a pendek dan mengajak sholat. Meskipun anak tidak mengerti apa-apa dan mengajari mengaji. Dan semua itu harus dibiasakan akan menjadi suatu kebiasaan pada diri anak. ${ }^{13}$

Hasil wawancara menunjukkan bahwa pembentukan karakter anak itu penting dimulai sejak usia dini. Dengan mengajarkan pendidikan agama terutama menumbuhkan kebiasaan untuk beribadah.

Begitu pula wawancara dengan ibu Bebun (ibu rumah tangga) mengatakan anak dari kecil harus diatur waktunya seperti waktu tidur, ngaji,

\footnotetext{
${ }^{13}$ Hartono, Wawancara, Desa Plososari, 21 April 2017.
} 


\section{Upaya Orang Tua Dalam Membentuk Karakter Anak Di Dusun Sumbersuko Desa Plososari Kecamatan Grati Kabupaten Pasuruan}

bermainnya. Pada saat waktu kegiatan anak berlangsung, orang tua harus menyesuaikannya. Waktu anak belajar orang tua tidak boleh nonton tv. ${ }^{14}$

Dari hasil wawancara tersebut menunjukkan bahwa usia dini anak sebaiknya orang tua sudah membekalinya dengan kedisiplinan dan pembiasaan. Disamping itu orang tua harus bisa menyeimbangi anak, tidak sekedar memerintah.

Wawancara dengan ibu Sukartini (guru) yang dilakukan pada tanggal 24 April 2017 mengatakan karakter anak sebenarnya sudah ada pada diri anak, orang tua hanya mengarahkan dengan membimbing, menasihati, meluruskan, mendo'akan pada karakter yang diinginkan. Kemudian menyekolahkannya agar mendapat pengetahuan dan bantuan pihak-pihak yang ada disekitar anak, karena tidak cukup hanya upaya dari orang tua saja. ${ }^{15}$

Dari hasil wawancara dengan ibu Sukartini menunjukkan bahwa pada diri anak sudah tertanam karakter, karakter yang kedepannya akan terbentuk sesuai dengan upaya orang tua menginginkan seperti apa karakter anak.

Lebih lanjut peneliti melakakukan wawancara dengan bapak Jumari mengatakan strategi dalam membentuk karakter anak dengan mengajari sopan santun, mencium tangan orang tua, mengucapkan salam, mengajak anak sholat berjama'ah, kalau ada tindakan anak yang salah dinasehati.16

\footnotetext{
${ }^{14}$ Bebun, Wawancara, Desa Plososari, 21 April 2017.

${ }^{15}$ Sukartini, Wawancara, Plososari, 21 April 2017.

16 Jumari, Wawancara, Plososari, 21 April 2017.
} 


\section{Ali Muhsin}

Hasil wawancara tersebut menunjukkan strategi yang dilakukan dalam membenuk karakter anak dengan cara memberi contoh atau menjadikan teladan bagi anak, melalui kebiasaan yang dilakukan sehari-hari, dengan begitu anak mengetahui mana yang sesuai dengan sekitarnya. Juga dengan cara menasihati apabila melakukan kesalahan.

Hal tersebut seseuai dengan apa yang dikemukakan Syarbini yaitu bahwa cara mendidik anak melalui keteladanan dan dilakukan sejak usia dini karena pada usia dini telah dapat melihat, mengenal dan mempelajari hal-hal yang berada di luar diri mereka. Mereka melihat dan diajarkan tentang sesuatu, dan pada dasarnya anak lebih banyak meniru dari apa yang dilakukan orang tuanya. Orang tua hendaklah melakukan didepan anaknya langsung jangan hanya melalui perkataan atau sekedar teori belaka. ${ }^{17}$

Apabila anak tidak mematuhi atau melanggar suatu peraturan, tindakan orang tua terhadap anaknya yaitu bersikap tegas kepada anak dengan cara menegur dan menasihatinya. Wawancara dengan bapak Hartono mengatakan dalam membentuk karakter anak harus dengan cara yang tegas agar anak bisa patuh pada apa yang orang tua katakan. Mengajak langsung dengan tindakan atau dengan mencontohkan apa yang harus diperbuat anak. dengan memberikan

\footnotetext{
${ }^{17}$ Amirulloh Syarbini, Buku Pintar Pindidikan Karakter (Jakarta : Prima Pustaka, 2012), 45.
} 


\section{Upaya Orang Tua Dalam Membentuk Karakter Anak Di Dusun Sumbersuko Desa Plososari Kecamatan Grati Kabupaten Pasuruan}

punishment ketika anak melakukan kesalahan dan memberikan reward jika sebaliknya. ${ }^{18}$

Hasil wawancara dengan bapak Hartono menunjukkan bahwa membentuk karakter anak harus dengan sikap tegas, bukan dengan kekerasan melainkan dengan sikap yang tegas yang sesuai dengan keadaan. Jika anak melakukan kesalahan orang tua harus memperlakukannya secara tegas dengan cara menegur dan menghukum dengan caranya masing-masing. Jika melakukan sesuatu yang membanggakan atau anak berprestasi maka akan mendapatkan penghargaan atau reward, agar anak lebih bersemangat dalam segala hal. Hal tersebut berupaya untuk anak supaya anak lebih mengerti mana yang boleh dan mana yang tidak dengan sikap tegas orang tua. Wawancara tentang strategi yang dilakukan orang tua dalam membentuk karakter dengan ibu Sukartini (guru) mengatakan memberikan keteladanan dalam bertindak, anak menganggap orang tua sebagai figur yang benar dan melakukannya secara terus menerus. Jika anak melakukan kesalahan ditegur dan dinasehati. ${ }^{19}$

Hasil wawancara dengan ibu Sukartini menunjukkan bahwa dalam membentuk karakter dimulai sejak dini juga memerlukan strategi dalam menyampaikan. Strategi yang biasa dilakukan yaitu dengan memberikan keteladanan atau contoh seperti mengajak anak sholat berjama'ah. Dan keteladanan tersebut harus dilakukan secara terus menerus atau berulang- ulang

\footnotetext{
${ }^{18}$ Hartono, Wawancara, Plososari, 21 April 2017.

${ }^{19}$ Sukartini, Wawancara, Plososari, 21 April 2017.
} 


\section{Ali Muhsin}

hingga menjadi suatu kebiasaan pada diri anak. Menegur dan menasihati juga merupakan strategi yang dilakukan dalam mebentuk karakter anak karena dengan menegur anak akan mengerti bahwa tindakannya salah. Dan juga menasihati bagaimana sebaiknya anak dalam bertindak dengan begitu anak akan merasa diperhatikan.

Wawancara dengan ibu Bebun terkait dengan strategi yang digunakan yaitu dengan melakukan pengawasan pada setiap kegiatan anak baik di rumah, sekolah, tempat bermain dengan tidak mengganggu ketenangan anak, juga selalu menunjukkan perilaku-perilaku yang baik seperti selalu pergi ke masjid untuk sholat berjama'ah, mengucapkan salam ketika akan keluar atau masuk rumah. Dan juga menegur tindakan anak yang salah dan membenahinya agar anak tidak mengulangi dan tahu yang bagaimana seharusnya anak perbuat. $^{20}$

Dalam upaya apapun untuk menuju sesuatu yang diinginkan pasti terdapat hambatan. Sesistematis apapun konsep dirancang, dengan cara atau strategi apapun yang digunakan tetap akan ditemukan hal-hal yang menyebabkan suatu konsep tersebut terhambat. Sebagaimana hal ini dalam upaya pembentukan karakter anak di dusun Sumbersuko desa Plososari kecamatan Grati kabupaten Pasuruan dalam mendidik dan membentuk karkter

${ }^{20}$ Bebun, Wawancara, Plososari, 21 April 2017. 


\section{Upaya Orang Tua Dalam Membentuk Karakter Anak Di Dusun Sumbersuko Desa Plososari Kecamatan Grati Kabupaten Pasuruan}

anak orang tua mengalami hambatan atau kendala. Adapun yang menjadi hambatan orang tua dalam membentuk karakter anak adalah :

Hambatan yang berasal dari dalam yaitu hambatan yang berasal dari orang tua dan anak. Hambatan yang berasal dari orang tua yaitu waktu untuk anak yang kurang karena kesibukan orang tua. Orang tua yang berprofesi sebagai buruh memiliki waktu yang berbeda dengan profesi yang lain dalam mengawasi anak.

Kesibukan orang tua mengakibatkan intensitas perjumpaan dengan anak sedikit apalagi orang tua tidak bisa mengontrol anak secara langsung. Sebagaimana wawancara dengan bapak Hartono mengatakan hambatan dalam membentuk karakter anak terdapat pada kurangnya waktu bersama anak, karena waktu yang lebih banyak dihabiskan untuk bekerja. ${ }^{21}$

Hasil wawancara menjelaskan bahwa hambatan dalam membentuk karakter anak adalah waktu kebersamaan orang tua dengan anak yang kurang, sehingga orang tua tidak bisa mengawasi dan mendidik anak secara terus menerus karena waktu bersama anak yang sedikit. Dan pengaruh Hp yang membuat anak lupa akan waktu.

Demikian ketika anak sudah senang dengan kegiatannya, maka akan lupa batas waktunya karena tidak ada yang mengawasi dan mengingatkannya. Anak dengan asiknya bermain karena orang tua tidak bersama anak. Sedangkan

\footnotetext{
${ }^{21}$ Hartono, Wawancara, Plososari, 21 April 2017.
} 


\section{Ali Muhsin}

faktor yang berasal dari anak yaitu sifat bosan yang pada akhirnya berujung pada tindakan malas yang membuat pembentukan karakter terhambat.

Wawancara dengan ibu Sukartini mengatakan hambatan yang dihadapi yaitu sifat bosan anak terhadap sesuatu yang sering dilakukan dan juga pengaruh lingkungan luar. Apabila anak bosan maka anak akan sulit untuk diajak belajar. Membiarkan anak dengan lingkungan luar tanpa ada pengawasan akan menjadikan anak liar, sedangkan melarang anak bergaul atau bermain dengan lingkungan sekitar akan membuat anak tidak bisa bersosial. ${ }^{22}$

Hasil wawancara menjelaskan bahwa hambatan yang dihadapi dalam membentuk karakter anak yaitu sifat bosan pada diri anak dengan sesuatu yang biasa dilakukan dan pengaruh lingkungan sekitar.

Hambatan yang berasal dari luar (ekstern) hasil wawancara dengan Jumari (petani) mengatakan dalam perjalanan membentuk karakter anak terhambat oleh lingkungan bermain anak yang sampai lupa waktu. Tapi jika diingatkan masih menurut dan jarang membantah. Anak kadang membantah kenapa beda dengan temannya yang boleh berbuat seenaknya seperti bermain sampai sore. ${ }^{23}$

Hal di atas menunjukkan bahwa pergaulan anak sangat berpengaruh dalam pembentukkan karakter, sehingga orang tua harus pintar dalam

\footnotetext{
${ }^{22}$ Sukartini, Wawancara, Plososari, 21 April 2017.

23 Jumari, Wawancara, Plososari, 21 April 2017.
} 


\section{Upaya Orang Tua Dalam Membentuk Karakter Anak Di Dusun Sumbersuko Desa Plososari Kecamatan Grati Kabupaten Pasuruan}

menghadapi anak yang merasa beda dengan temannya sampai anak memahami apa tindakan orang tuanya.

Wawancara dengan ibu Bebun mengatakan anak kalau sudah bermain lupa akan waktu, jika sudah main hp akan lupa pada aktifitas lainnya dan anak yang merasa beda dengan temannya dan akhirnya meniru apa yang dilakukan temannya. ${ }^{24}$

Hasil wawancara diatas menunjukkan bahwa hambatan dari luar atau lingkungan luar dan teknologi sangat besar dalam membentuk karakter anak.

Pada saat anak sudah menggunakan teknologi mereka akan asik dengan kegiatannya, yang kemudian sulit diajak untuk melakukan aktifitas yang lain. Begitu pula ketika anak sudah dalam lingkungan bermain, mereka (anak) sampai lupa waktu.

Berdasarkan hal di atas maka pengaruh lingkungan bermain dan teknologi baik informasi maupun komunikasi. Dampaknya adalah anak menjadi malas dan terkadang anak selalu menunda-nunda untuk melakukan suatu tindakan seperti menunda waktu sholat, belajar, istirahat dan terkadang menyepelekan orang tua ketika diberi nasihat, apalagi sekarang ini media sosial berupa facebook dan permainan atau game bisa dibuka melalui fitur yang ada di hp tanpa harus ke warnet.

\footnotetext{
${ }^{24}$ Bebun, Wawancara, Plososari, 21 April 2017.
} 


\section{Ali Muhsin}

\section{G. Kesimpulan}

Setelah penulis membahas, meneliti, dan menganalisa hasil-hasil penelitian sebagaimana yang telah direncanakan, maka peneliti dapat menyimpulkan beberapa hal sebagai berikut:

Upaya orang tua dalam membentuk karakter anak yaitu dengan mendidik anak dimulai sejak usia dini melalui menanamkan pendidikan agama, nilai-nilai dan norma-norma dimana anak tinggal. Juga dengan menyekolahkan anak agar mendapat ilmu pengetahuan yang lebih terutama pada pembentukan karakter.

Strategi yang dilakukan dalam membentuk karakter anak antara lain melalui keteladanan, pembiasaan, kedisiplian, nasihat, reward dan punishment. Di dusun Sumbersuko desa Plososari kecamatan Grati kabupaten pasuruan lebih banyak yang menggunakan strategi melalui keteladanan.

Hambatan orang tua dalam membentuk karakter anak di dusun Sumbersuko desa Plososari kecamatan Grati kabupaten Pasuruan, terdiri dari faktor internal yaitu kesibukan orang tua dan sifat bosan yang ada pada anak, faktor eksternal yaitu pengaruh pergaulan di lingkungan bermain anak, dan pengaruh teknologi informasi dan komunikasi (hp). 


\section{Upaya Orang Tua Dalam Membentuk Karakter Anak Di Dusun Sumbersuko Desa Plososari Kecamatan Grati Kabupaten Pasuruan \\ DAFTAR PUSTAKA}

Adhim, M. Fauzil. 2004. Adventures in Parenting: Yogyakarta. Alenia. Agung, Iskandar dan Rumtini. 2010. Civil Society dan Pendidikan Karakter Bangsa. Jurnal Pendidikan dan Kebudayaan. Jakarta. Balitbang Kemendiknas.

Amini, Mukti. 2008. Pengasuhan Ayah Ibu yang Patut, Kunci Sukses Mengembangkan Karakter Anak. Yogyakarta. Tiara Wacana.

Arikanto, Suharsimi. 2006. Prosedur Penelitian Suatu Pendekatan Praktik. Jakarta. Rineka Cipta.

Asymuni, Yasin. 2016. Berbakti kepada Orang Tua: Kediri. PP. Hidayatut Thullab.

Departemen Agama Republik Indonesia. 2009. Al-Qur'an dan Terjemahannya Special for Woman. Jakarta. Sigma.

Departemen Pendidikan Nasional. 2001. Kamus Besar Bahasa Indonesia. Jakarta. Balai Pustaka.

Haryono dan Amirul Hadi. 2005. Metodologi Penelitian Pendidikan. Bandung. Pustaka Setia.

Hidayar, Asep Yusuf. 2007. Prosedur Penelitian Pendekatan Praktis. Bandung. Rosada Karya.

Hidayatulloh, Furqon. 2010. Pendidikan Karakter: Membangun Peradaban Bangsa. Surakarta. Yuma Pustaka.

Ihsan, Fuad. 2010. Dasar-Dasar Kependidikan: Komponen MKMD. Jakarta. PT: Rineka Cipta.

Lickona, Thomas. 2012. Educating for Character: How Our Schools Can Teach Respect and Responsibility. Jakarta: PT: Bumi Aksara.

Margono, S. 1997. Metodologi Penelitian Pendidikan. Jakarta. Rineka Cipta.

Moelang, Lexy J. 2007. Metodologi Penelitian Kualitatif. Bandung. PT. Remaja Rosdakarya. 
Ali Muhsin

150 | Dinamika Vol. 2, No. 2, Desember 2017 